\title{
Stages of in vitro phagocytosis of Plasmodium falciparum- infected erythrocytes by human monocytes
}

\author{
Estágios da fagocitose in vitro por monócitos humanos de eritrócitos infectados \\ por Plasmodium falciparum
}

\author{
Maria Imaculada Muniz-Junqueira ${ }^{1,2}$ and Carlos Eduardo Tosta ${ }^{1,2}$
}

\begin{abstract}
Monocytes/macrophages play a critical role in the defense mechanisms against malaria parasites, and are the main cells responsible for the elimination of malaria parasites from the blood circulation. We carried out a microscope-aided evaluation of the stages of in vitro phagocytosis of Plasmodium falciparum-infected erythrocytes, by human monocytes. These cells were obtained from healthy adult individuals by means of centrifugation through a cushion of Percoll density medium and were incubated with erythrocytes infected with Plasmodium falciparum that had previously been incubated with a pool of anti-plasmodial immune serum. We described the stages of phagocytosis, starting from adherence of infected erythrocytes to the phagocyte membrane and ending with their destruction within the phagolisosomes of the monocytes. We observed that the different erythrocytic forms of the parasite were ingested by monocytes, and that the process of phagocytosis may be completed in around 30 minutes. Furthermore, we showed that phagocytosis may occur continuously, such that different phases of the process were observed in the same phagocyte.
\end{abstract}

Key-words: Phagocytosis. Monocytes. Plasmodium falciparum.

\section{RESUMO}

Monócitos/macrófagos desempenham uma função crítica nos mecanismos de defesa antiplasmódio e constituem as principais células responsáveis pela eliminação das formas eritrocitárias do plasmódio da circulação sanguínea. Realizamos uma avaliação microscópica dos estágios da fagocitose in vitro de eritrócitos infectados por Plasmodium falciparum por monócitos humanos. Essas células foram obtidas de indivíduos adultos sadios por centrifugação em Percoll e incubadas com eritrócitos infectados por Plasmodium falciparum previamente incubados com um pool de soro imune contra plasmódio. Descrevemos os estágios da fagocitose, desde a aderência dos eritrócitos infectados até sua destruição nos fagolisossomas dos monócitos. Observou-se que eritrócitos infectados por todos os diferentes estágios assexuados do parasito foram ingeridos pelos monócitos e que 0 processo de fagocitose pode se completar em cerca de 30 minutos. Além disso, mostramos que a fagocitose pode ocorrer de uma forma contínua, de tal maneira que diferentes fases do processo foram observadas no mesmo fagócito.

Palavras-chaves: Fagocitose. Monócitos. Plasmodium falciparum.

It has been recognized that monocytes/macrophages play a critical role in the defense against malaria parasites, and are the main cells responsible for the clearance of blood forms of the parasite from the circulation ${ }^{49}$. Peripheral blood monocytes ${ }^{13}$ and spleen and liver macrophages ${ }^{11}$ show considerable phagocytic activity towards parasitized erythrocytes, particularly when anti-parasite antibodies are present ${ }^{40}$. It has been shown that monocytes plus anti-plasmodial antibodies are able to decrease

\footnotetext{
1. Laboratório de Imunologia Celular, Faculdade de Medicina, Universidade de Brasília, Brasília, DF. 2. Laboratório de Malária, Núcleo de Medicina Tropical, Universidade de Brasília, Brasília, DF.

Financial support: Conselho Nacional de Desenvolvimento Científico e Tecnológico (CNPq), Brazil (040.0020/90-4/FV; 74379/2003-5.4).

Address to: Dra. Maria Imaculada Muniz-Junqueira. Laboratório de Imunologia Celular/FM/UnB. Campus Darci Ribeiro, Asa Norte, 70910-900 Brasília, DF.

Fax: $55613273-3907$

e-mail: mimjunqueira@unb.br

Recebido para publicação em 27/06/2008

Aceito em 27/11/2008
}

the in vitro growth of Plasmodium falciparum by nearly $80 \%$. However, the nature of the process of phagocytosis of Plasmodium falciparum-infected erythrocytes by human monocytes has not so far been fully clarified. Therefore, we have described the stages of in vitro phagocytosis of erythrocytes infected with Plasmodium falciparum, by human blood monocytes, in the presence of antiplasmodial antibodies.

\section{MATERIAL AND METHODS}

Subjects, cells and serum samples. Human blood monocytes were obtained from heparinized venous blood collected from healthy adult volunteers who had no present or past episodes of malaria, and who had never been to areas of malaria transmission. The process of phagocytosis was evaluated in the presence of a pool of anti-plasmodial immune serum, obtained from 44 individuals infected with Plasmodium falciparum who were living in an endemic malarial area in Brazil. The serum 
samples were pooled, aliquoted, and kept at $-70^{\circ} \mathrm{C}$ until used in the in vitro tests and were thawed only once. When tested using indirect immunofluorescence, with the isolate Pf/UnB-169 of Plasmodium falciparum as the antigen, the serum pool showed titers of 160 for IgM and 640 for IgG.

Plasmodium falciparum isolate. The Pf/UnB-169 isolate of Plasmodium falciparum was kept under continuous culturing conditions, modified from Trager and Jansen ${ }^{12}$, in $0^{+}$erythrocytes with $4 \%$ hematocrit. It was suspended in complete RPMI 1640 medium buffered with 20mM of HEPES and 7.5\% $\mathrm{NaHCO}_{3}$, and was supplemented with $0.25 \mathrm{mg} / \mathrm{dl}$ of hypoxanthine and $10 \%$ heat-inactivated $\mathrm{AB}^{+}$human serum in an atmosphere of synthetic air plus $5 \% \mathrm{CO}_{2}$ at $37^{\circ} \mathrm{C}$.

Test of phagocytosis. Peripheral blood mononuclear cells were obtained from healthy adult individuals by means of centrifugation through a cushion of Percoll (Pharmacia, Uppsala, Sweden), density 1,077 , at $750 \mathrm{~g}$ for $15 \mathrm{~min}$ at $4^{\circ} \mathrm{C}$, followed by two washings at $400 \mathrm{~g}$ and $200 \mathrm{~g}^{14}$, and suspended into cold RPMI 1640 medium (Sigma, St. Louis, USA), pH 7.2, supplemented with 20mM HEPES (Sigma, St. Louis, USA), 2mM glutamine (Sigma, St Louis, USA), and $2.5 \mathrm{mg} / \mathrm{dl}$ of gentamicin. Cell viability was assessed using $0.05 \%$ nigrosin solution in $0.15 \mathrm{M}$ phosphate-buffered saline (PBS), $\mathrm{pH} 7.2$, and was found to be always higher than $97 \%$. The test of phagocytosis of erythrocytes infected with Plasmodium falciparum was adapted from a technique previously described ${ }^{6}$. Briefly, monocytes from individual volunteers were separated by adherence to 13-mm-diameter round glass coverslips in 24-well plastic plates (Flow, MacLean, USA) after incubation in a wet chamber for $2 \mathrm{~h}$ at $37^{\circ} \mathrm{C}$, in the presence of $5 \% \mathrm{CO}_{2}$ in air. After rising the coverslips with PBS, adherent cells (>99\% monocytes, with an average of 26,000 $\pm 4,200$ cells/coverslip) were incubated, in duplicate preparations, with 100 erythrocytes infected with Plasmodium falciparum per monocyte, for $30 \mathrm{~min}$ at $37^{\circ} \mathrm{C}$ in a wet chamber with $5 \% \mathrm{CO}_{2}$ in air. Infected erythrocytes were first incubated for $30 \mathrm{~min}$ at $37^{\circ} \mathrm{C}$ with $10 \%$ pool of anti-Plasmodium falciparum immune serum and thoroughly washed afterward. The mean $\pm \mathrm{SD}$ of parasitemia of Plasmodium falciparum-infected erythrocytes used in the tests was $13 \pm 4 \%$, with predominance of mature forms of the parasite (mature trophozoites and schizonts). Next, the coverslips were thoroughly rinsed with $\mathrm{PBS}$ at $37^{\circ} \mathrm{C}$ to eliminate the erythrocytes that were not strongly adhering to monocytes. Cells were then fixed with absolute methanol, stained with 10\% Giemsa solution in PBS (pH 7.2) and examined under an optical microscope at 1,000x magnification.

The duration of the incubation period for the phagocytosis evaluation was defined from previous experiments in which monocytes collected from three individuals were incubated with infected erythrocytes for 10, 15, 20, 25, 30 and $45 \mathrm{~min}$, in duplicate preparations, in the same way as described above. The assessment of phagocytosis under the microscope showed that adherence of infected erythrocytes to monocytes was detectable as early as after 10 min of incubation. Twenty minutes later, degenerated parasites were present in the monocytic phagolysosomes. The incubation period of $30 \mathrm{~min}$ was chosen for our observations because, at that time, all stages of phagocytosis could be identified and the developmental phases of the parasite could be distinguished.
Ethical issues. The ethical rules of the Helsinki Declaration and those of the Brazilian National Health Council, Ministry of Health, for experiments on humans, were strictly observed throughout this work.

\section{RESULTS}

Figures 1-6 show the stages of in vitro phagocytosis of erythrocytes infected with Plasmodium falciparum by human monocytes, starting with adherence of the infected erythrocytes to the phagocytes and ending with the destruction of the parasites within phagolysosomes. It was observed that erythrocytes infected by the different stages of the parasite were phagocytized. Figure 1 shows an erythrocyte infected with a ring form, at the beginning of the phagocytosis process, while Figure 2 shows the phagocytosis of an erythrocyte infected with a trophozoite form and Figure 3,

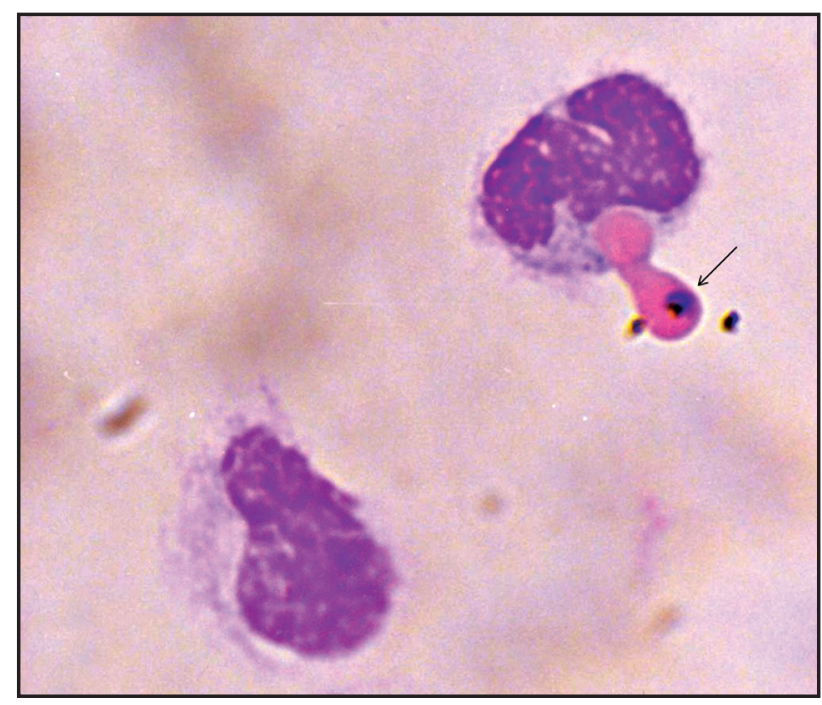

FIGURE 1

Erythrocyte infected with a ring form of Plasmodium falciparum (arrow), adhering to a monocyte: the first step of phagocytosis. Giemsa staining, 1,000x magnification.

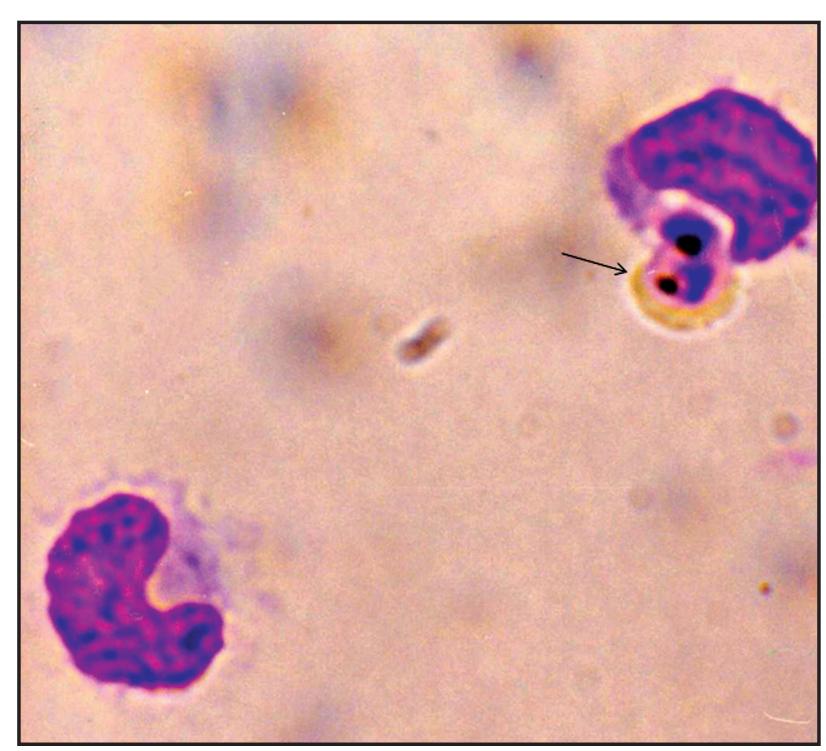

FIGURE 2

Adherence of an erythrocyte infected with two trophozoites of Plasmodium falciparum (arrow) to a blood monocyte. Giemsa staining, 1,000x magnification. 
with a schizont form. A further step in the phagocytosis process is shown in Figure 4, in which a trophozoite is contained within a phagosome, and the erythrocyte membrane is no longer seen. In Figure 5, the phagocytosis process is reaching its end, and

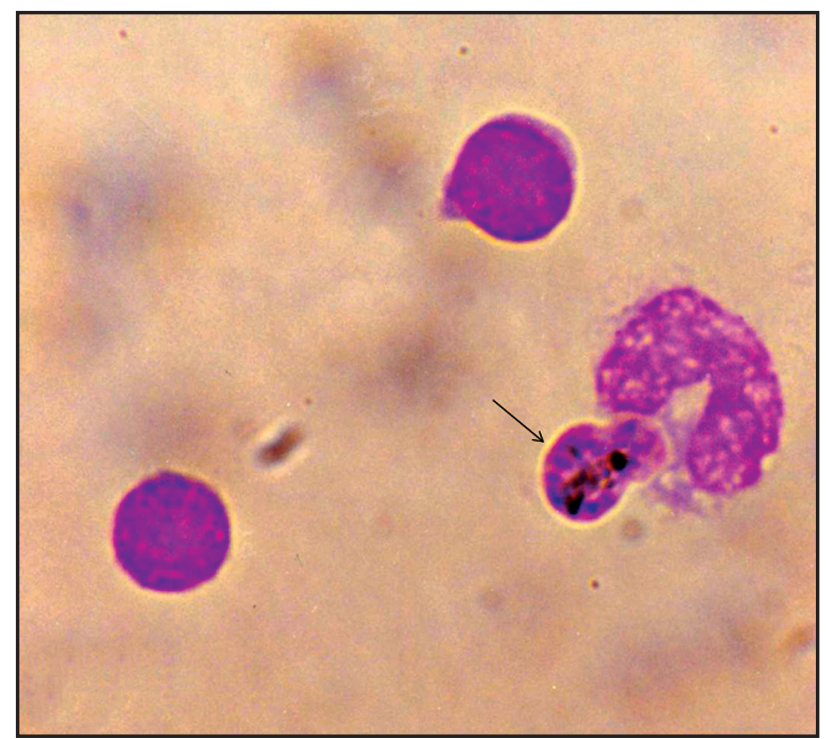

FIGURE 3

Erythrocyte infected with schizont of Plasmodium falciparum (arrow), adhering to a monocyte. Giemsa staining, 1,000x magnification.

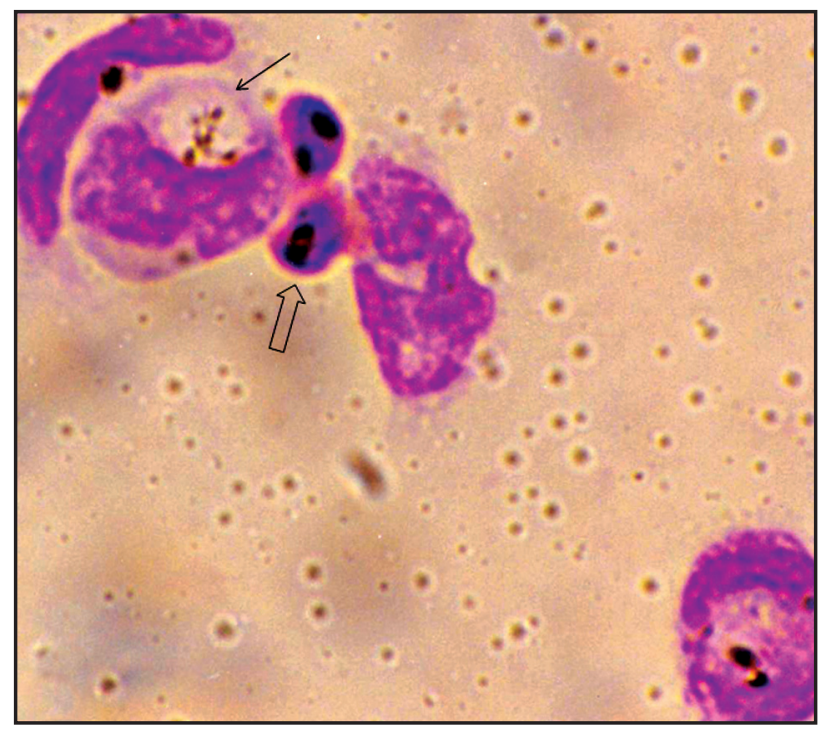

FIGURE 5

Remnants of Plasmodium falciparum (narrow arrows) within monocyte phagosome. Two other Plasmodium falciparum-infected erythrocytes adhering to the same monocyte (wide arrows). Giemsa staining, 1,000x magnification.

\section{DISCUSSION}

It is already established that blood phagocytes contribute towards the defense against malaria parasites ${ }^{1513}$, and possibly play a part in the pathogenic effects of parasite sequestration in the microcirculation.

Our present investigation adds further information on the process of phagocytosis of Plasmodium falciparuminfected erythrocytes by human monocytes. We showed that only remnants of the parasite are present in the monocytic phagolysosome. This and Figure $\mathbf{6}$ show that different stages of phagocytosis can be found in the same monocyte, thus suggesting that this process is highly dynamic.

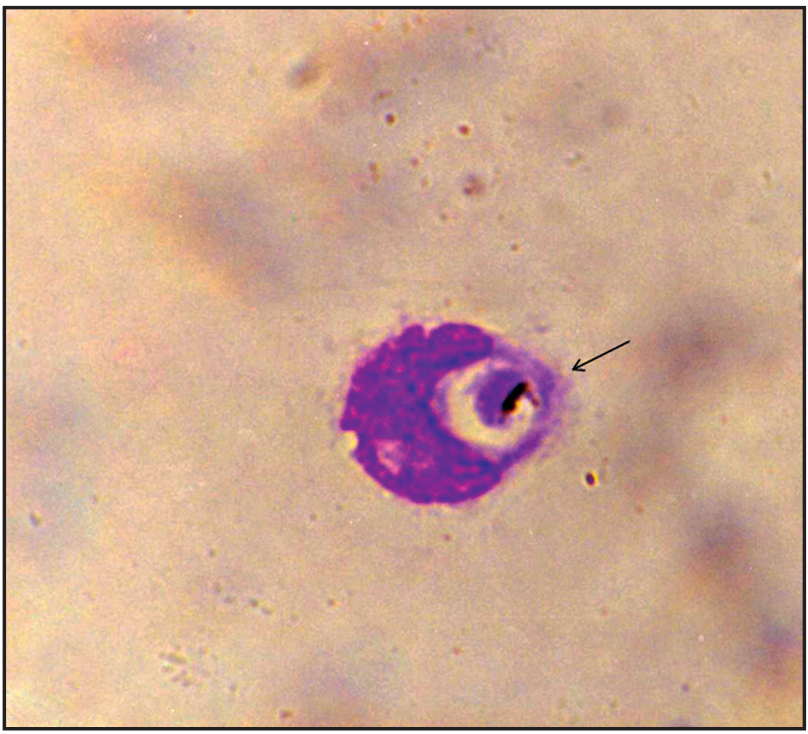

FIGURE 4

A trophozoite of Plasmodium falciparum (arrow), observed within the phagosome of a monocyte. Giemsa staining, 1,000x magnification.

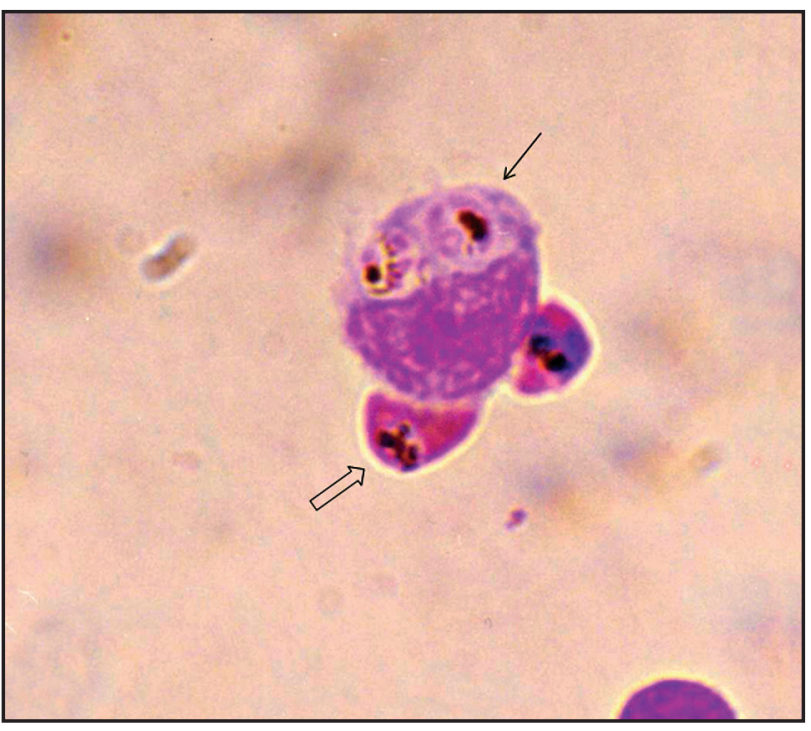

FIGURE 6

Remnants of Plasmodium falciparum (narrow arrows) within monocyte phagosome, and two other erythrocytes infected with Plasmodium falciparum adhering to the same cell (wide arrow). Giemsa staining, 1,000x magnification.

all developmental forms of intra-erythrocytic Plasmodium falciparum are susceptible to adherence, ingestion and destruction by monocytes, and that the whole process may be completed within about 30 minutes, which was the duration of the incubation period chosen for our observations.

Adherence of erythrocytes infected with Plasmodium falciparum to monocytes induces ingestion and involves the expression of different membrane receptors, including mannosefucose and glucan receptors, the CR1 and CR3 complement 
receptors, and the $\mathrm{Fc} \gamma$ receptor $^{2} 315$. The latter plays a crucial role in the phagocytosis of parasitized erythrocytes, such that this process is increased by $100 \%$ when immune serum is added to the system 7 . This receptor was operative in our system, since it is expressed in recently collected monocytes ${ }^{8}$ and we incubated the parasitized erythrocytes with a pool of immune serum sample containing $\operatorname{IgG}$ specific to Plasmodium falciparum.

The finding that all asexual erythrocytic stages of Plasmodium falciparum were phagocytized in the presence of immune serum suggests that antibodies against these stages may be operative in this process. Furthermore, it indicates that individuals infected with Plasmodium falciparum produce antibodies against the different developmental stages of malarial parasites. This observation may contribute towards better understanding of hostparasite immunology in Plasmodium falciparum infection.

In conclusion, this study described the stages of phagocytosis of erythrocytes infected with Plasmodium falciparum, starting from adherence of the infected cells to the monocyte membrane and ending with their destruction within the phagocyte phagolysosomes. We found that all erythrocytic forms of the parasite are ingested by monocytes, and that the whole process of phagocytosis may be completed in about 30 minutes. Furthermore, it was also found that phagocytosis may occur continuously, such that different phases of the phagocytosis process are observed in the same phagocyte.

\section{ACKNOWLEDGMENTS}

The authors thank Mr. Nelson P. Nascimento, Mrs. Renê 0. Pires, Mrs. Rozeneide Magalhães and Mr. José Siqueira for technical assistance; and Mr. Paulo H.B. Leite for documentation.

\section{REFERENCES}

1. Arese P, Turrini F, Ginsburg H. Erythrophagocytosis in malaria: host defense or menace to the macrophage? Parasitology Today 7: 25-27, 1991.
2. Campagne ML, Wiesmann C, Brown EJ. Macrophage complement receptors and pathogen clearance. Cellular Microbiology 9: 2095-2102, 2007.

3. Flesch BK, Vöge K, Henrichs T, Neppert J. Fc $\gamma$ receptor-mediated immune phagocytosis depends on the class of Fc $\gamma \mathrm{R}$ and on the immunoglobulin-coated target cell. Vox Sanguinis 81: 128-133, 2001.

4. Groux H, Gysin J. Opsonization as an effector mechanism in human protection against asexual blood stages of Plasmodium falciparum: Functional role of IgG subclasses. Research in Immunology 141: 529-542, 1990.

5. McGregor IA. Malarial immunity: current trends and prospects. Annals of Tropical Medicine and Parasitology 81: 647-656, 1987.

6. Muniz-Junqueira MI, Prata A, Tosta CE. Factors influencing phagocytosis of Salmonella typhimurium by macrophages in murine schistosomiasis. Revista da Sociedade Brasileira de Medicina Tropical 30: 101-106, 1997.

7. Muniz-Junqueira MI, Santos-Neto LL, Tosta CE. Influence of tumor necrosis factor- $\alpha$ on the ability of monocytes and lymphocytes to destroy intraerythrocytic Plasmodium falciparum in vitro. Cellular Immunology 208: 73-79, 2001.

8. Stein M, Keshav S. The versatility of macrophages. Clinical and Experimental Allergy 22: 19-27, 1992.

9. Theander TG. Defense mechanisms and immune evasion in the interplay between the human immune system and Plasmodium falciparum. Danish Medical Bulletin 39: 49-63, 1992.

10. Tosta CE. Effects of the immune and hyperimmune serum on the dynamics of phagocytosis of Plasmodium berghe $i$-infected erythrocytes. Revista do Instituto de Medicina Tropical de São Paulo 24: 140-147, 1982.

11. Tosta CE, Ruiz G, Wedderburn N. Effects of lethal and non-lethal malaria on the mononuclear phagocyte system. Revista da Sociedade Brasileira de Medicina Tropical 16: 58-67, 1983.

12. Trager W, Jensen JB. Human malaria parasites in continuous culture. Science 193: 673-675, 1976.

13. Turrini F, Ginsburg H, Bussolino F, Pescarmona GP, Serra MV, Arese P. Phagocytosis of Plasmodium falciparum-infected human red blood cells by human monocytes: Involvement of immune and non-immune determinants and dependence on parasitic developmental stage. Blood 80: 801-808, 1992.

14. Ulmer AJ, Flad HD. Discontinuous density gradient separation of human mononuclear leukocytes using Percoll as gradient medium. Journal of Immunology Methods 30: 1-10, 1979.

15. Underhill DM, Ozinsky A. Phagocytosis of microbes: complexity in action. Annual Review of Immunology 20: 825-852, 2002. 